\title{
ДИНАМИКА ПОКАЗАТЕЛЕЙ ЭНЕРГОПОТРЕБЛЕНИЯ И ЭНЕРГОЭФФЕКТИВНОСТИ РОССИЙСКИХ ПРОМЫШЛЕННЫХ ПРЕДПРИЯТИЙ
}

\author{
(c) 2018 Лозенко Валерий Константинович
}

доктор технических наук, профессор кафедры экономики в энергетике и промышленности Национальный исследовательский университет «Московский Энергетический Институт» 111250 , г. Москва, ул. Красноказарменная, д. 14

E-mail: lozenkovk@yandex.ru

(c) 2018 Михеев Дмитрий Владимирович

кандидат экономических наук

ассистент кафедры электроснабжения промышленных предприятий и электротехнологий Национальный исследовательский университет «Московский Энергетический Институт»

111250, г. Москва, ул. Красноказарменная, д. 14

E-mail: arctic-fox17@yandex.ru

(c) 2018 Сухарева Евгения Викторовна

кандидат экономических наук, доцент кафедры экономики в энергетике и промышленности Национальный исследовательский университет «Московский Энергетический Институт»

111250, г. Москва, ул. Красноказарменная, д. 14

E-mail: SukharevaYevV@mpei.ru

(c) 2018 Шиндина Татьяна Александровна

доктор экономических наук, доцент

директор Института дополнительного дистанционного образования

Национальный исследовательский университет «Московский Энергетический Институт»

111250, г. Москва, ул. Красноказарменная, д. 14

E-mail: ShindinaTA@mpei.ru

В работе представлен анализ показателей энергопотребления и энергоэффективности российской промышленности (по видам экономической деятельности) в посткризисный период. Приведены и обработаны данные по структуре энерго- и электропотребления, доле затрат и динамике расходов российских промышленных предприятий на энергоресурсы, энергоемкости и индикаторам энергоэффективности российских промышленных предприятий. Охарактеризованы причины и последствия низкой энергоэффективности российской промышленности, представлены фактические данные о внедрении международного стандарта по энергоменеджменту ISO 50001:2011 в практику управления российских и зарубежных организаций.

Ключевые слова: промышленность, энергопотребление, энергоэффективность, энергоемкость, устойчивое развитие, ISO 50001:2011.

Одной из ключевых целей в достижении устойчивого развития (УР) промышленности является обеспечение рационального, эффективного и безопасного использования топливно-энергетических ресурсов (ТЭР). Для оценки взаимосвязанности процессов энергоиспользования, их эффективности и УР в первую очередь необходимо иметь объективные сведения о доле потребления электроэнергии и других видов ТЭР промышленностью в структуре конечного потребления [9]. В табл. 1 представлена структура конечного энергопотребления предприятиями промышленности и по РФ в целом в тоннах условного топлива (т у.т.) в 2015 г. (детализированная информация в ретроспективе по видам ТЭР приведена в [13], в динамике данная структура не претерпевает серьезных изменений). Промышленные предприятия являются наиболее крупными энергопотребителями и электропотребителями (табл. 2) в структуре конечного

" Исследование выполнено при финансовой поддержке РФФИ в рамках научного проекта № 18-010-00883 А. 
Таблица 1. Структура конечного потребления ТЭР промышленными предприятиями в общем конечном энергопотреблении РФ в 2015 г. [14]

\begin{tabular}{|l|c|c|c|}
\hline \multicolumn{1}{|c|}{ Потребитель ТЭР } & $\begin{array}{c}\text { Общее потребление } \\
\text { ТЭР, млн. т у.т. }\end{array}$ & $\begin{array}{c}\text { Доля в общем энерг- } \\
\text { потреблении,\% } \\
\text { промышленновти в } \\
\text { структуре промыш- } \\
\text { ленного энергопотре- } \\
\text { бления,\% }\end{array}$ \\
\hline Конечное энергопотребление по РФ & 887 & $100,00 \%$ & $100,00 \%$ \\
\hline Промышленность РФ & 415 & $47 \%$ & $19 \%$ \\
\hline Добыча полезных ископаемых & 79 & $9 \%$ & $66 \%$ \\
\hline Обрабатывающие производства & 274 & $31 \%$ & $15 \%$ \\
\hline $\begin{array}{l}\text { Производство и распределение } \\
\text { электроэнергии, газа и воды }\end{array}$ & 62 & $7 \%$ & \\
\hline
\end{tabular}

Источник. Дополнено и рассчитано авторами по статистическим данным Росстата [14]

Таблица 2. Динамика потребления электроэнергии промышленными предприятиями в общей структуре электропотребления РФ в 2013-2015 гг. [13]

\begin{tabular}{|c|c|c|c|c|c|}
\hline \multirow[b]{2}{*}{ Год } & \multirow[b]{2}{*}{$\begin{array}{c}\text { Электропотребле- } \\
\text { ние по РФ }\end{array}$} & \multirow[b]{2}{*}{$\begin{array}{c}\text { Промышленность } \\
\text { РФ }\end{array}$} & \multicolumn{3}{|c|}{ Сектора промышленности } \\
\hline & & & $\begin{array}{c}\text { Добыча полезных } \\
\text { ископаемых }\end{array}$ & $\begin{array}{c}\text { Обрабатывающие } \\
\text { производства }\end{array}$ & $\begin{array}{c}\text { Производство и } \\
\text { распределение } \\
\text { электроэнергии, } \\
\text { газа и воды }\end{array}$ \\
\hline \multicolumn{6}{|c|}{ Электропотребление секторами промышленности, млрд. кВт·ч } \\
\hline 2013 & 1054,8226 & 564,9872 & 139,434 & 314,896 & 110,658 \\
\hline 2014 & 1064,9561 & 561,1371 & 139,185 & 308,683 & 113,270 \\
\hline 2015 & 1060,2378 & 559,2264 & 139,676 & 312,173 & 107,378 \\
\hline \multicolumn{6}{|c|}{ Доля электропотребления секторами промышленности в общем электропотреблении в РФ,\% } \\
\hline 2013 & 100,00 & 53,56 & 13,22 & 29,85 & 10,49 \\
\hline 2014 & 100,00 & 52,69 & 13,07 & 28,99 & 10,64 \\
\hline 2015 & 100,00 & 52,75 & 13,17 & 29,44 & 10,13 \\
\hline \multicolumn{6}{|c|}{ Доля электропотребления секторами промышленности в электропотреблении промышленностью в РФ,\% } \\
\hline 2013 & 2 & 100,00 & 24,68 & 55,73 & 19,59 \\
\hline 2014 & $=$ & 100,00 & 24,80 & 55,01 & 20,19 \\
\hline 2015 & $\longrightarrow$ & 100,00 & 24,98 & 55,82 & 19,20 \\
\hline
\end{tabular}

Источник. Систематизировано и рассчитано авторами по данным Росстата [13]

потребления ТЭР в РФ (на их долю приходится более $50 \%$ от всех потребленных ТЭР в стране). Наиболее весомый вклад в формирование такой структуры вносят обрабатывающие производства ( 34\% от общего конечного энергопотребления по РФ и $~ 70 \%$ от общего конечного энергопотребления по промышленности РФ).

Наибольшую долю в структуре электропотребления занимает расход электроэнергии на двигательную нагрузку - 55\%, далее следует расход электроэнергии на технологические нужды - 25\%, на освещение, собственные нужды электростанций и потери электроэнергии приходится около 20\% в динамике.

Результаты анализа статистических данных Росстата свидетельствуют о том, что наибольшее потребление энергоресурсов и воды в финансовом выражении также приходится на долю промышленности (почти 60\% от суммарных затрат на энергоресурсы и воду по экономике РФ в соответствии с рис. 1) [13]. Данный факт обусловлен тем, что промышленные предприятия РФ являются крупнейшими энергопотребителями и в натуральном выражении.

Это делает актуальной задачу снижения издержек предприятий на ТЭР и водные ресурсы с целью высвобождения финансовых средств, которые могут быть инвестированы в обеспечение их экономической, экологической и социальной устойчивостей.

Доля затрат на приобретение ТЭР и водных ресурсов в структуре общих затрат предприя- 


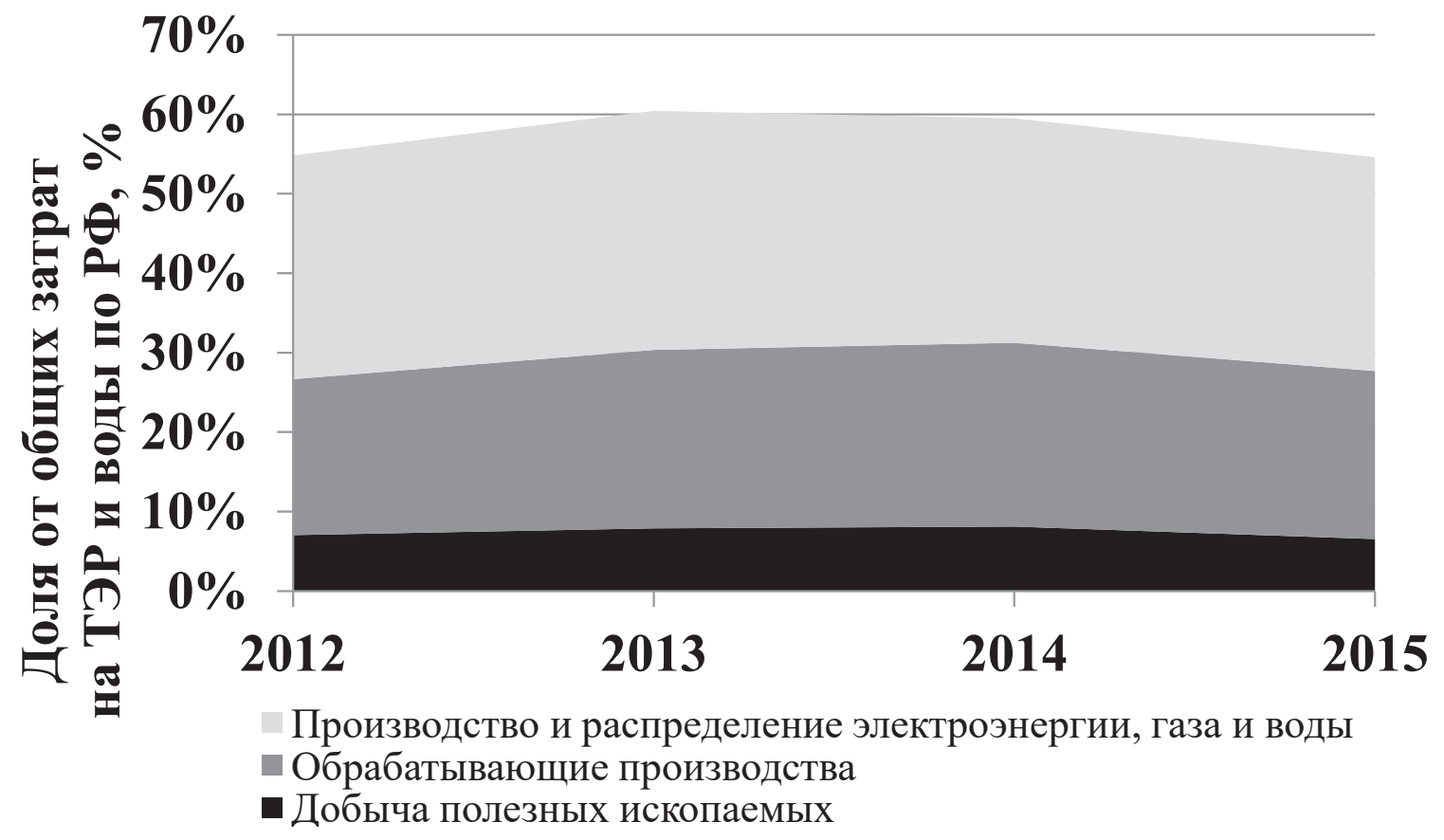

Puc. 1. Динамика изменения расходов на оплату ТЭР и воды секторами промышленности в 2013-2015 гг.,\% Источник. Построено авторами по данным Росстата [13, 14]

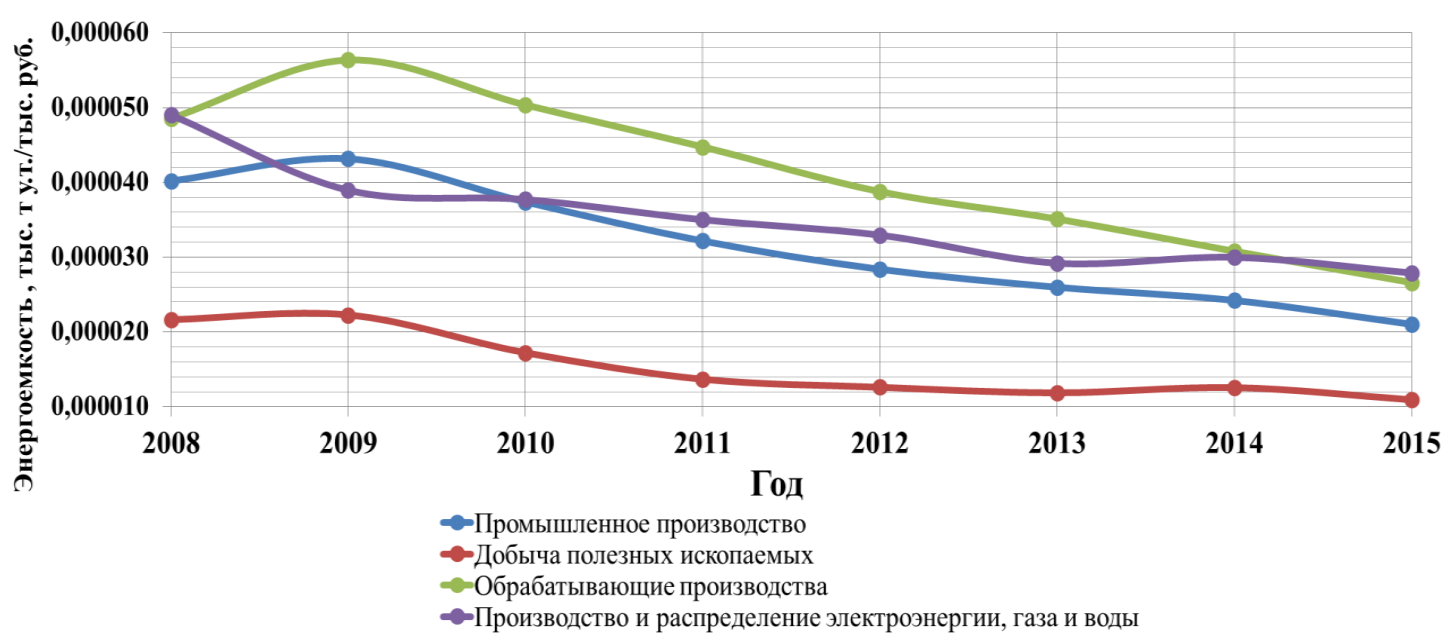

Puc. 2. Динамика изменения энергоемкости ВВП секторов промышленности в 2008-2015 гг., тыс. т у.т./тыс. руб. Источник. Построено авторами по данным Росстата $[13,14]$

тиями всех трех секторов промышленности и в структуре промышленности в целом не является одинаковым для каждого сектора промышленности ввиду различных энерготехнологических процессов. Так, по данным Росстата затраты на приобретение ТЭР и водных ресурсов у предприятий по добыче полезных ископаемых составляют 6\%, у обрабатывающих производств - 2-3\%, у предприятий по производству и распределению электроэнергии, газа и воды - 33-34\%, в среднем по всем промышленным предприяти- ям - около 6\%. При этом Т.С. Мещерякова в [10] отмечает, что «доля энергозатрат в себестоимости некоторых видов продукции, работ и услуг промышленных предприятий достигает порядка 30-40\%, что значительно превышает аналогичные показатели стран ЕС, США и КНР» [10].

Для расчета динамики изменения с 2008 по 2015 гг. энергоемкости ВВП промышленности (отношение конечного потребления ТЭР в тыс. т у.т. к значению ВВП промышленных предприятий РФ в тыс. руб.) (рисунок 2) авторами были 
использованы статистические данные Росстата [13, 14].

Динамика изменения энергоемкости ВВП промышленности РФ свидетельствует о постепенном снижении данного показателя, однако, наблюдаемые темпы не являются достаточными для достижения поставленных государством целей в области энергоэффективности и энергосбережения и обусловлены в большей степени не повышением энергоэффективности промышленного производства, а иными факторами, подробно описанными в [4]. Таким образом, промышленный сектор РФ имеет высокий технический и экономический потенциал энергосбережения (более 100 млн. т у.т.) [4]. Реализация данного потенциала позволила бы снизить энергоемкость промышленности РФ на 25\%, которая (как и энергоемкость экономики РФ в целом) превышает аналогичный показатель КНР на 30\%, США - в 2 раза, развитых стран Евросоюза и Японии - в 2,5-3 раза (в расчете на \$ по паритету покупательской способности) [8]. Причины и последствия низкого уровня энергоэффективности российской промышленности систематизированы автором и представлены в табл. 3.

Повышение эффективности использования ТЭР является приоритетной задачей для промышленности всех государств, что находит отклик в международных и национальных документах. Примеры успешной реализации законодательных мер в области энергоэффективности имеются в ведущих экономиках мира: США в значительной степени сократили импорт нефти, вывели существенное количество устаревших угольных тепловых электростанций

\section{Таблица 3. Причины и последствия низкого уровня энергоэффективности} российской промышленности

\begin{tabular}{|c|c|}
\hline № & Причины низкой энергоэффективности российской промышленности \\
\hline 1 & Неблагоприятные естественно-климатические и географические условия. \\
\hline 2 & Энергоемкая структура российской экономики. \\
\hline 3 & $\begin{array}{l}\text { Высокий уровень издержек и низкая рентабельность ряда предприятий, нестабильная экономическая } \\
\text { ситуация как в хозяйственно-производственной деятельности предприятий, так и в целом в экономи- } \\
\text { ке РФ. }\end{array}$ \\
\hline 4 & $\begin{array}{l}\text { Устаревшая, изношенная и практически необновляемая материально-техническая база и технологи- } \\
\text { ческая отсталость, усугубляемые дефицитом инвестиционных вложений в развитие инфраструктуры. }\end{array}$ \\
\hline 5 & Высокая доля дорогого импортного энергоэффективного оборудования на рынке. \\
\hline 6 & $\begin{array}{l}\text { Недостаточная инновационная активность предприятий, выраженная в недостаточном (не массовом) } \\
\text { производстве и внедрении инновационных технологий и продуктов. }\end{array}$ \\
\hline 7 & $\begin{array}{l}\text { Высокий уровень рисков и неудовлетворительная экономическая эффективность реализации некото- } \\
\text { рых энергосберегающих мероприятий (инвестиционных проектов). }\end{array}$ \\
\hline 8 & $\begin{array}{l}\text { Информационный дефицит в сфере энергосбережения и энергоэффективности и отсутствие понима- } \\
\text { ния важности эффективности процессов энергоиспользования у населения и персонала промышлен- } \\
\text { ных предприятий. }\end{array}$ \\
\hline 9 & $\begin{array}{l}\text { Неэффективное функционирование организационно-экономических механизмов по управлению } \\
\text { энергоэффективностью организаций (только 1\% российских промышленных предприятий получил } \\
\text { сертификат соответствия требованиям MC ISO 50001:2011 [2]). }\end{array}$ \\
\hline 10 & $\begin{array}{l}\text { Направленность государственной политики в области повышения энергоэффективности в основном } \\
\text { на макроэкономические факторы [8]. }\end{array}$ \\
\hline 11 & Отсутствие достаточного уровня мотивации персонала в сфере энергосбережения. \\
\hline № & Последствия низкой энергоэффективности российской промышленности \\
\hline 1 & $\begin{array}{l}\text { Препятствия для обеспечения кардинального повышения конкурентоспособности отечественных } \\
\text { предприятий, товаров и услуг на российском и мировом рынках. }\end{array}$ \\
\hline 2 & $\begin{array}{l}\text { Ухудшение экономической и финансовой устойчивости предприятия и отвлечение потенциальных } \\
\text { инвестиционных средств (например, в модернизацию производства, природоохранную деятельность } \\
\text { и социальную сферу) из-за нерациональных расходов на приобретение ТЭР. }\end{array}$ \\
\hline 3 & Снижение интегральной эффективности производственных процессов. \\
\hline 4 & $\begin{array}{l}\text { Отсутствие экономии первичного органического топлива, которое могло бы быть направлено на экс- } \\
\text { порт и принести дополнительный доход в бюджет страны. }\end{array}$ \\
\hline 5 & Нестабильная экологическая и социально-экономическая обстановки. \\
\hline 6 & егральной устойчивости функционирования предприятий. \\
\hline
\end{tabular}

Источник. Составлено авторами 
(ТЭС), а Китай стал лидером в области возобновляемых источников энергии (ВИЭ) [9]. Российское законодательство в сфере энергосбережения и энергоэффективности составляет свыше 40 нормативно-правовых актов [7], а одними из ключевых задач российской экономики в области энергоэффективности являются «снижение энергоемкости ВВП на 13,5\% к 2020 г. относительно показателя 2007 г., экономия первичных энергоносителей объемом 170-180 млн. т у.т. к 2020 г., снижение выбросов парниковых газов на 393 млн. т экв. СО2 к 2020 г., увеличение доли ВИЭ (без учета крупных гидроэлектростанций) в энергобалансе страны до 2,50\% к 2020 г.» [7]. При этом принятие нормативно-правовых документов и применение их положений на практике является дополнительным фактором повышения энергоэффективности, но не определяющим (табл. 3).

В настоящее время различные ИЭЭ в той или иной интерпретации находят широкое применение и являются неотъемлемой частью во многих системах индикаторов УР $[5,6,9,12]$. В работах $[1,5]$ С.Н. Бобылева и его соавторов отмечается, что «применение ИЭЭ может обеспе- чить объективный, комплексный и интегральный учет социально-экономико-экологических факторов устойчивого развития».

В мировой практике международные неправительственные и научные организации активно используют общепринятые универсальные ИЭЭ, среди которых следует отметить: «Динамика энергоемкости» (ВВП, ВНП, ВРП, выпуска продукции, товаров и услуг и т.д.) [5], «Динамика объема общего и конечного потребления ТЭР» (в общем натуральном и финансовом выражениях и в структурном разрезе энергопотребителей)» [6], «Доля использования ВИЭ в структуре потребления ТЭР» [9]. Подобные индикаторы, приведенные в качестве примера в таблице 4 (с учетом динамики их изменения), можно идентифицировать, анализируя статистические данные функционирования российской экономики и производственно-технологическую деятельность российских промышленных предприятий.

Существенный результат в области повышения энергоэффективности функционирования российских промышленных предприятий может быть достигнут при внедрении в практику управления международного стандарта (MC)

Таблица 4. Примеры ИЭЭ российской экономики и промышленности $[13,14]$

\begin{tabular}{|c|c|c|}
\hline Наименование ИЭЭ & Ед. измерения & Фактические значения \\
\hline Электропотребление в РФ & тыс. кВт·ч & см. таблицу 1 \\
\hline Общее энергопотребление & млн. т у.т. & $\begin{array}{l}2014 \text { г. }-2584,9 \text { млн. т у.т. } \\
2015 \text { г. } 2543,5 \text { млн. т У.т. }\end{array}$ \\
\hline Конечное энергопотребление в РФ & млн. т у.т. & см. таблицу 1 \\
\hline \multirow{3}{*}{$\begin{array}{l}\text { Фактический средний расход элек- } \\
\text { троэнергии, теплоэнергии и то- } \\
\text { плива на единицу произведенной } \\
\text { продукции (на примере чугуна) }\end{array}$} & кг у.т./Т & $\begin{array}{l}2012 \text { г. }-551,1 \text { кг У.т./т } \\
2016 \text { г. }-545,1 \text { кг У.т./т }\end{array}$ \\
\hline & $\mathrm{kBT} \cdot \mathrm{u} / \mathrm{T}$ & $\begin{array}{l}2012 \text { г. }-19,3 \mathrm{kBT} \cdot \mathrm{\varphi} / \mathrm{T} \\
2016 \text { г. }-18,5 \mathrm{\kappa BT} \cdot \mathrm{\varphi} / \mathrm{T}\end{array}$ \\
\hline & Гкал/т & $\begin{array}{l}2012 \text { г.-0,0281 Гкал/т } \\
2016 \text { г.-0,0263 Гкал/т }\end{array}$ \\
\hline Энергоемкость промышленности & тыс. т у.т./тыс. руб. & см. рис. 2 \\
\hline $\begin{array}{l}\text { Доля энергоресурсов, произведен- } \\
\text { ных в РФ за счет ВИЭ от общего } \\
\text { объема }\end{array}$ & $\%$ & $\begin{array}{l}2012 \text { г. }-15,3 \% \\
2016 \text { г. }-17,0 \%\end{array}$ \\
\hline $\begin{array}{l}\text { Уровень использования нефтяного } \\
\text { попутного газа }\end{array}$ & $\%$ & $\begin{array}{l}2012 \text { г. }-75,9 \% \\
2016 \text { г. }-87,6 \%\end{array}$ \\
\hline $\begin{array}{l}\text { Выбросы парниковых газов, свя- } \\
\text { занные с энергетикой }\end{array}$ & млн. т СО2-эквивалента & $\begin{array}{l}2011 \text { г. }-2226,87 \text { млн. т } \\
2014 \text { г. }-2191,15 \text { млн. т }\end{array}$ \\
\hline $\begin{array}{l}\text { Потери электроэнергии при пере- } \\
\text { даче в магистральном электросе- } \\
\text { тевом комплексе РФ (ПАО «ФСК } \\
\text { ЕЭС») }\end{array}$ & $\%$ & $\begin{array}{l}2015 \text { г. }-4,09 \% \\
2016 \text { г. }-4,63 \%\end{array}$ \\
\hline \multirow{2}{*}{$\begin{array}{l}\text { Удельный расход условного топли- } \\
\text { ва на выработку электроэнергии } \\
\text { и тепловой энергии (ПАО «Мосэ- } \\
\text { нерго») }\end{array}$} & $\Gamma / \mathrm{KBT} \cdot \mathrm{\Psi}$ & $\begin{array}{l}2015 \text { г. }-233 \text { г/кВт·ч } \\
2016 \text { г. }-232 \text { г/кВТ·ч }\end{array}$ \\
\hline & г/Гкал & $\begin{array}{l}2015 \text { г. - } 165 \text { г/Гкал } \\
2016 \text { г. }-164 \text { г/Гкал }\end{array}$ \\
\hline
\end{tabular}

Источник. Данные ПАО «ФСК ЕЭС», ПАО «Мосэнерго» и Росстата $[13,14]$ 
ISO 50001:2011 «Energy management systems Requirements with guidance for use» [2], что подтверждается успешными примерами крупных российских компаний и стран СНГ (ПАО «ЛУКОЙЛ», Нефтяная компания «Роснефть», ООО «УГМК-Холдинг», МРСК Центра и Приволжья, АО «КЭЗ» и др.), которые были описаны в [8, 9]. В период с 2011 по 2016 гг. всего в мире было выдано 20216 сертификатов соответствия требованиям MC ISO 50001:2011, из них 8231 шт. - в 2016 г. [3] (детализированная статистика в региональном разрезе приведена в табл. 5).

Наибольший интерес к внедрению требований данного МС в практику управления организаций наблюдается в развитых странах ЕС (прежде всего, в Германии, Великобритании и Италии) - свыше 65\% от общего количества выданных сертификатов. Промышленными предприятиями за весь период было получено 8667 сертификатов ( $43 \%$ от общего количества). В отраслевом разрезе наибольшее количество сертифицированных организаций на 2016 г. наблюдается в металлургической отрасли (1052 шт. $-5,20 \%)$, пищевой отрасли (805 шт. $-3,98 \%)$, в производстве резины и пластмассы (764 шт.3,78\%), в химической промышленности (763 шт.- 3,77\%) и в производстве электротехнического и оптического оборудования (376 шт.1,86\%). В РФ за указанный период было всего выдано 174 сертификата, из них: в 2011 г. -1 шт.,

Таблица 5. Сведения о количестве организаций, получивших сертификаты соответствия требованиям MC ISO 50001:2011 (нарастающим итогом)

\begin{tabular}{|c|c|c|c|c|c|c|}
\hline Год & 2011 & 2012 & 2013 & 2014 & 2015 & 2016 \\
\hline \multicolumn{7}{|c|}{ ВСЕГО В МИРЕ } \\
\hline Выданные сертификаты, шт. & 459 & 2236 & 4826 & 6765 & 11985 & 20216 \\
\hline Темпы прироста,\% & - & $387 \%$ & $116 \%$ & $40 \%$ & $77 \%$ & $69 \%$ \\
\hline \multicolumn{7}{|c|}{ Африка } \\
\hline Выданные сертификаты, шт. & 0 & 13 & 36 & 18 & 40 & 58 \\
\hline Доля от общего количества,\% & $0,0 \%$ & $0,6 \%$ & $0,7 \%$ & $0,3 \%$ & $0,3 \%$ & $0,3 \%$ \\
\hline Темпы прироста,\% & - & $100 \%$ & $177 \%$ & $-50 \%$ & $122 \%$ & $45 \%$ \\
\hline \multicolumn{7}{|c|}{ Южная и Центральная Америка } \\
\hline Выданные сертификаты, шт. & 11 & 10 & 34 & 63 & 92 & 81 \\
\hline Доля от общего количества,\% & $2,4 \%$ & $0,4 \%$ & $0,7 \%$ & $0,9 \%$ & $0,8 \%$ & $0,4 \%$ \\
\hline Темпы прироста,\% & - & $-9 \%$ & $240 \%$ & $85 \%$ & $46 \%$ & $-12 \%$ \\
\hline \multicolumn{7}{|c|}{ Северная Америка } \\
\hline Выданные сертификаты, шт. & 1 & 9 & 34 & 77 & 77 & 73 \\
\hline Доля от общего количества,\% & $0,2 \%$ & $0,4 \%$ & $0,7 \%$ & $1,1 \%$ & $0,6 \%$ & $0,4 \%$ \\
\hline Темпы прироста,\% & - & $800 \%$ & $278 \%$ & $126 \%$ & $0 \%$ & $-5 \%$ \\
\hline \multicolumn{7}{|c|}{ Европа } \\
\hline Выданные сертификаты, шт. & 364 & 1919 & 3993 & 5526 & 10152 & 17102 \\
\hline Доля от общего количества,\% & $79,3 \%$ & $85,8 \%$ & $82,7 \%$ & $81,7 \%$ & $84,7 \%$ & $84,6 \%$ \\
\hline Темпы прироста,\% & - & $427 \%$ & $108 \%$ & $38 \%$ & $84 \%$ & $68 \%$ \\
\hline \multicolumn{7}{|c|}{ Восточная Азия и Океания } \\
\hline Выданные сертификаты, шт. & 49 & 191 & 478 & 693 & 1035 & 2086 \\
\hline Доля от общего количества,\% & $10,7 \%$ & $8,5 \%$ & $9,9 \%$ & $10,2 \%$ & $8,6 \%$ & $10,3 \%$ \\
\hline Темпы прироста,\% & - & $290 \%$ & $150 \%$ & $45 \%$ & $49 \%$ & $102 \%$ \\
\hline \multicolumn{7}{|c|}{ Центральная и Южная Азия } \\
\hline Выданные сертификаты, шт. & 26 & 76 & 189 & 299 & 459 & 663 \\
\hline Доля от общего количества,\% & $5,7 \%$ & $3,4 \%$ & $3,9 \%$ & $4,4 \%$ & $3,8 \%$ & $3,3 \%$ \\
\hline Темпы прироста,\% & - & $192 \%$ & $149 \%$ & $58 \%$ & $54 \%$ & $44 \%$ \\
\hline \multicolumn{7}{|c|}{ Ближний Восток } \\
\hline Выданные сертификаты, шт. & 8 & 18 & 62 & 89 & 130 & 153 \\
\hline Доля от общего количества,\% & $1,7 \%$ & $0,8 \%$ & $1,3 \%$ & $1,3 \%$ & $1,1 \%$ & $0,8 \%$ \\
\hline Темпы прироста,\% & & $125 \%$ & $244 \%$ & $44 \%$ & $46 \%$ & $18 \%$ \\
\hline
\end{tabular}

Источник. International Standard Organisation (ISO) [2] 
в 2012 г. -7 шт., в 2013 г. -17 шт., в 2014 г. -56 шт., в 2015 г. -37 шт., в 2016 г. -56 шт.

Наилучшие показатели в сфере повышения энергоэффективности имеют европейские страны с наибольшим количеством сертифицированных предприятий, среди которых преобладают промышленные (табл. 6).

В соответствии со статистическими данными ISO [3] и Enerdata [11] в большинстве стран (более 80\%) происходит устойчивое снижение энергоемкости ВВП на фоне увеличения количества организаций, получивших сертификаты соответствия МС в сфере энергоэффективности. Страны, демонстрирующие отрицательную динамику снижения энергоемкости ВВП, являются в основном экспортерами углеводородных ТЭР, а организации данных стран имеют незначительное количество полученных сертификатов соответствия (например, РФ). Российские организации, внедрившие СЭнМ на базе ISO 50001:2011 (менее 0,1\% на конец 2016 г. от общего количества промышленных организаций [13]), имеют возможность эффективно управлять процессами энергоиспользования в своей деятельности и улучшают показатели энергоэффективности, что подтверждается фактическими данными [8]. При этом они не способны изменить ситуацию в области энергоэффективности в стране в целом.

Методология обработки и формирования статистических баз данных Росстата, ISO и Enerdata и используемые при этом допущения приведены на официальных веб-сайтах организаций [3, 11, 13]. При анализе некоторых показателей использовались непродолжительные по времени статистические ряды из-за несущественного изменения рассматриваемых показателей за достаточно длительный период времени (начиная с 2010 г.). Статистические данные по некоторым из показателей за 2016-2017 гг. не приведены ввиду их отсутствия в официальных

Таблица 6. Корреляция между энергоемкостью ВВП (по паритету покупательской способности на 2015 г.) стран и количеством полученных сертификатов соответствия требованиям MC ISO 50001:2011

\begin{tabular}{|c|c|c|c|c|c|c|c|}
\hline Страны & Ед. & 2011 & 2012 & 2013 & 2014 & 2015 & 2016 \\
\hline \multirow{2}{*}{ Среднемировой показатель } & шт. & 459 & 2236 & 4826 & 6765 & 11985 & 20216 \\
\hline & кг Н.э./\$ & 0,130 & 0,128 & 0,125 & 0,123 & 0,119 & 0,117 \\
\hline \multirow{2}{*}{ Бельгия } & шт. & 0 & 16 & 21 & 28 & 43 & 70 \\
\hline & кг Н.э./\$ & 0,113 & 0,108 & 0,112 & 0,104 & 0,104 & 0,109 \\
\hline \multirow{2}{*}{ Великобритания } & шт. & 11 & 136 & 330 & 376 & 1464 & 2829 \\
\hline & кг Н.э./\$ & 0,076 & 0,077 & 0,074 & 0,068 & 0,066 & 0,064 \\
\hline \multirow{2}{*}{ Германия } & шт. & 42 & 1133 & 2477 & 3402 & 5931 & 9024 \\
\hline & кг Н.э./\$ & 0,082 & 0,082 & 0,084 & 0,079 & 0,079 & 0,078 \\
\hline \multirow{2}{*}{ Индия } & шт. & 25 & 74 & 172 & 271 & 405 & 570 \\
\hline & кг Н.э./\$ & 0,117 & 0,117 & 0,112 & 0,111 & 0,106 & 0,104 \\
\hline \multirow{2}{*}{ Иран } & шт. & 0 & 1 & 14 & 29 & 48 & 65 \\
\hline & кг Н.э./\$ & 0,145 & 0,162 & 0,168 & 0,173 & 0,175 & 0,166 \\
\hline \multirow{2}{*}{ Испания } & шт. & 95 & 127 & 196 & 310 & 390 & 465 \\
\hline & кг Н.э./\$ & 0,078 & 0,080 & 0,076 & 0,074 & 0,074 & 0,072 \\
\hline \multirow{2}{*}{ Италия } & шт. & 30 & 74 & 258 & 294 & 470 & 1415 \\
\hline & кг Н.э./\$ & 0,072 & 0,071 & 0,069 & 0,065 & 0,068 & 0,067 \\
\hline \multirow{2}{*}{ KHP } & шт. & & 3 & 3 & 60 & 262 & 1015 \\
\hline & ке н.э./\$ & 0,183 & 0,176 & 0,168 & 0,159 & 0,150 & 0,143 \\
\hline \multirow{2}{*}{ ОАЭ } & шт. & 4 & 6 & 25 & 33 & 47 & 48 \\
\hline & ке Н.э./\$ & 0,112 & 0,114 & 0,111 & 0,118 & 0,114 & 0,112 \\
\hline \multirow{2}{*}{ РФ } & шт. & 1 & 8 & 25 & 81 & 118 & 174 \\
\hline & кг Н.э./\$ & 0,213 & 0,211 & 0,203 & 0,203 & 0,204 & 0,205 \\
\hline \multirow{2}{*}{ Франция } & шт. & 3 & 37 & 86 & 270 & 500 & 759 \\
\hline & кг Н.э./\$ & 0,094 & 0,094 & 0,094 & 0,089 & 0,090 & 0,087 \\
\hline \multirow{2}{*}{ Чехия } & шт. & 1 & 10 & 16 & 32 & 73 & 369 \\
\hline & к2 Н.э./\$ & 0,130 & 0,130 & 0,130 & 0,123 & 0,118 & 0,114 \\
\hline
\end{tabular}

Источник. Разработано авторами на основе данных ISO [3] и Enerdata [11] 
источниках. В этой связи в работе используется старая классификация разделов видов экономической деятельности в соответствии с ОКВЭД. В итоге исследований можно сделать следующие два основных вывода.

1. Российские промышленные предприятия вносят весомый вклад в формирование ВВП РФ, испытывают инвестиционный и инновационный дефицит, имеют высокую степень импортозависимости на фоне неблагоприятной для РФ политической и экономической ситуации, имеют потребность в системной модернизации основных фондов, являются источниками дестабилизации экологической обстановки и социально значимыми объектами экономики, крупнейшими потребителями ТЭР с достаточно низким уровнем энергоэффективности в сравнении с развитыми странами. Особенности функционирования современных российских промышленных предприятий свидетельствуют о необходимости обеспечения их УР по экономической, экологической и социальной составляющим УР. Неудовлетворительные показатели энергоэффективности функционирования промышленных предприятий обусловлены рядом причин, среди которых одной из основных является непроработанность организационно-экономических механизмов управления энергоэффективностью, функционирование которых направлено на обеспечение УР промышленных организаций.

2. Одним из наиболее перспективных направлений по повышению энергоэффективности и устойчивости функционирования российских промышленных предприятий является внедрение организационно-экономического механизма управления энергоэффективностью на основе требований MC ISO 50001:2011.

\section{Библиографический список}

1. Bobylev S.N., Chereshnya O.Y., Kulmala M., Lappalainen H.K., Petäjä T., Solov'eva S.V., Tikunov V.S., Tynkkynen $V$. Indicators for digitalization of sustainable development goals in PEEX Program // GEOGRAPHY, ENVIRONMENT, SUSTAINABILITY. 2018. Vol. 11. № 1. pp. 145-156. DOI: http://dx.doi.org/10.24057/2071-93882018-11-1-145-156.

2. ISO 50001:2011 «Energy management systems - Requirements with guidance for use» [Electronic resource] / ISO. URL: http://www.iso.org/iso/catalogue_detail?csnumber=51297 (date of access: 18.05.2015).

3. ISO Survey of certifications to management system standards - Full results [Electronic resource] / ISO. URL: https://isotc.iso.org/livelink/livelink?func=ll\&objId=18808772\&objAction=browse\&viewType=1 (date of access: 20.09.2018).

4. Башмаков И.А. Повышение энергоэффективности в российской промышленности. Что делать! // Энергосовет. 2013. № 3(28). С. 41-56.

5. Бобылев С.Н., Аверченков А.А., Соловьева С.В., Кирюшин П.А. Энергоэффективность и устойчивое развитие // Институт устойчивого развития / Центр экологической политики России. Москва. 2010. 148 с.

6. Бобылев С.Н., Зубаревич Н.В., Соловьева С.В., Власов Ю.С. Устойчивое развитие: методология и методики измерения. Москва. 2011. 358 с.

7. Законодательство [Электронный ресурс] / Министерство энергетики РФ. URL: http://minenergo.gov.ru/ documents/zakon (дата обращения: 13.03.2018).

8. Лозенко В.К., Агеев М.К. Развитие организационных механизмов - ключевой фактор инновационного прогресса в управлении энергоэффективностью // Журнал «Контроллинг». 2012. № 1 (43). С. 55-61.

9. Лозенко B.K., Михеев Д.В. Управление энергоэффективностью и устойчивое развитие организаций // Saarbrücken, LAP LAMBERT Academic Publishing, 2016. 284 c.

10. Мещерякова Т.С. Управление энергозатратами промышленного предприятия на основе использования энергосервисного контракта: автореферат дис. канд. экон. наук: 08.00.05. Москва, 2015. 25 с.

11. Мировая энергетическая статистика. Ежегодник 2018 [Электронный ресурс] / Enerdata. URL: https://yearbook. enerdata.ru (дата обращения: 20.08.2018).

12. Михеев Д.В. Управление энергоиспользованием промышленного предприятия на основе индикаторов энергоэффективности // Экономика и управление: проблемы, решения. 2017. Т. 4 (65). № 5-2. С. $171-177$.

13. Официальная статистика [Электронный ресурс] / Федеральная служба государственной статистики. URL: http://www.gks.ru/wps/wcm/connect/rosstat_main/rosstat/ru/statistics/ (дата обращения: 21.03.2018).

14. Промышленное производство в России. 2016: Стат. сб. / Росстат. М., 2016. 347 с. 